\title{
Analysis of Innovation Attributes in The Innovation Adoption of Agricultural Mechanization Technology in Farmers
}

\author{
Dyah Gandasari $^{1, *}$, Dayat $^{2}$, Diena Dwidienawati $^{3}$, Larassati Sri Wahyuni ${ }^{1}$
}

1 Politeknik Pembangunan Pertanian Bogor, Bogor 16730, Indonesia

2 Politeknik Pembangunan Pertanian Bogor, Bogor 16119, Indonesia

3 Universitas Bina Nusantara, Jakarta 11530, Indonesia

${ }^{*}$ E-mail: dyah.gandasari@gmail.com

Sumbitted: 01 October 2020 | Accepted: 18 March 2021 | Published online: 06 April 2021

\section{ABSTRACT}

In the last 4-6 years, the government has provided an agricultural mechanization assistance through the Ministry of Agriculture to Gapoktan, Poktan or the Agricultural Equipment and Machinery Service Business (UPJA). Assistance is provided in order to support increased production and productivity of superior commodities. It is suspected that the use of alsintan has not been optimally utilized. In order to optimize the utilization of this government innovation, the optimization is carried out by analyzing the adoption and the use of alsintan and implementing the optimization of machinery. This study is limited to character analysis of the innovation that affects the speed of adoption of alsintan innovation in farmers in Bogor, Sukabumi and Cianjur districts. The unit of research analysis was individual alsintan user farmers. The samples were determined purposively. There were 158 selected respondents. The descriptive statistical analysis used was Microsoft Excel 2016. The results showed there were some influences of innovation attributes on the adoption of two-wheeled hand tractor and water pump innovations. Farmers can make use of innovation because it reduces production costs, makes work easier, and increases production. Besides, it is easy to use and easy to test; and the results are easy to see. Further research is needed to analyze the environment, organizations and individuals as the driving factors for innovation adoption.

Keywords: compatibility, complexity, observability, relative advantage, trialability

Content from this work may be used under the terms of the Creative Commons Attribution-ShareAlike 4.0 International. Any further distributionof this work must maintain attribution to the author(s) and the title of the work, journal citation and DOI.

Published under Department of Communication and Community Development Science, IPB University and in association with Forum Komunikasi Pembangunan Indonesia and Asosiasi Penerbitan Jurnal Komunikasi Indonesia.

E-ISSN: 2442-4102 | P-ISSN: 1693-3699 


\section{INTRODUCTION}

The Ministry of Agriculture targets that Indonesia can become the world food barn in 2045. One of the efforts that has been carried out is by increasing agricultural production to meet domestic demand as well as export. The production target of rice in 2018 was 86.4 million tons or increased by 5\% compared to 2017, which was 82.3 million tons. One of the efforts to increase production was through an innovation, i.e., modernizing agricultural equipment and machinery.

According to Sulaiman et al. (2018) modernization of agricultural mechanization in Indonesia is still considered low, that is only 1.30 Horse Power/hectare (in 2013). Based on the data, one of the agricultural development programs was improving the technology of farming by applying a massive mechanization technology (Sulaiman et al., 2018).

Modernization of agricultural machinery was carried out to increase the quantity and quality of agricultural products and to enable farmers to compete in the local as well as international markets. The innovation in the form of alsintan assistance was aimed to enable farmers to adopt innovation so that they can compete in the farming development and improve their lives to become better. Technological innovation proved to be the source of development and improvement of agricultural products and farmers' income (Syakir, 2015).

The Ministry of Agriculture provided more than 284 million units of alsintan assistance in the period of 2015-2017 (Sulaiman et al., 2018). The type of alsintan that the government provided was twowheeled tractors and water pumps. It was assumed that the alsintan assistance had not been used optimally; therefore, an alsintan optimization program was carried out, among others, analysis of alsintan application and implementation of alsintan optimization. This research was limited to the analysis of innovation characteristics to enable farmers to adopt the innovation of agricultural mechanization technology quickly.

The theoretical approach used was the innovation features of Rogers (2003). According to Rogers (2003) there were 5 innovation characteristics, each of which was empirically related to one another, but conceptually different. The five features were relative advantage, compatibility, complexity, trialability, and observability. These characteristics were based on the following: 1) the level of expediency or advantage of the innovation from the aspects of economy and status, 2) the suitability of the innovation with the existing cultural values and level of needs, 3) the level of an innovation that is perceived to be relatively difficult to understand or use, 4) the level in which an innovation is worth trying in a limited scale, and 5) the level in which the results are visible (Rogers, 2003).

Research on farmers' adoption and sustainability of farmers' choice to adopt was influenced by factors that were related to farmers' characteristics, such as the activity of an extension institution and the farmers' managerial capacity (Adekambi et al., 2020; Bavorová et al., 2020; Kurnia, 2014; Wadsworth, 1995), individual behavior to choose technological use independently (Frank, 1995, 1997), human behavior based on behavioral precursor (Alemayehu et al., 2020), the influence of socio-culture environment (Heffernan et al., 2008), technology (Pagliacci et al., 2020; Serah, 2013), attitude and motivation as well as the farmers' socio-economy characteristics (Deng et al., 2016; Luo et al., 2016; Page \& Bellotti, 2015; Pagliacci et al., 2020; Sasongko, 2016; Trischler et al., 2020). These factors have been widely studied by considering the farmers' adoption.

Most research on adoption behavior concentrates on farmers' characteristics as the driving factor of adoption. As a matter of fact, to make the agricultural development strategies efficient needs not only farmers' behavior, but variables related to innovation attributes, economic climate, structural constraints and technology suitability must also be included into the model to increase the predictability of adoption behavior (Wadsworth, 1995). For that reason, the research, one of which referred to Roger's five innovation characteristics, was still relevant and important to understand further the farmers' adoption. A lot of research on innovation attributes has been carried out by Efendy \& Hutapea (2010) on rice cultivation, Harianta (2010) and Adnan et al. (2019) on the use of organic fertilizers on rice plants, Rushendi (2017) on integration of lemon grass-livestock, and Warnaen et al. (2016) on adoption obstacle factors in the farmer community of rice, corn and chili. However, research related to innovation attributes on farmers' adoption and sustainability of farmers' choice to adopt modern alsinta in order to modernize farming has not much been carried out. 
Research on alsintan innovation characteristics was expected to give an overview of innovation characteristics that would influence the speed of alsintan innovation diffusion in some districts in Indonesia. The research objective was to analyze innovation characteristics that affected the speed of alsintan innovation in farmers in Bogor, Sukabumi and Cianjur.

\section{METHODS}

The research was located in the Regency of Bogor, Sukabumi and Cianjur. These regencies are the areas that received alsintan assistance, and they are easily reached in terms of the limited research fund. The research was carried out from October 2018 to February 2019.

The unit analysis of the research was a farmer individual as the representative of farmer groups, the receivers of alsintan assistance. Respondents were determined in a convenience way. There were 158 farmers as the representatives of farmer groups from 9 districts in Sukabumi, 3 districts from Cianjur and 2 districts from Bogor.

The primary data were obtained from direct questionnaires completed by the respondents. Data collected were processed and analyzed by descriptive statistics using Microsoft Excel 2016. The secondary data were obtained from the village office and district office as well as the Agricultural Office in each of the Regency of Bogor, Sukabumi and Cianjur.

\section{RESULTS AND DISCUSSION}

\section{Characteristics of the farmer individual}

Age. The age category used in this research was based on the Department of Health (2015). The department of Health has divided age according to four categories, namely early adult (26-35 years), late adult (36-45 years), early elderly ( $46-55$ years) and late elderly (56-65 years). The number and percentage of farmers according to age from the 158 respondents can be seen in Table 1.

Table 1. Number and percentage of farmers according to age, 2018

\begin{tabular}{cccc}
\hline Age (years) & Category & $\begin{array}{c}\text { Number of Respondents } \\
\text { (person) }\end{array}$ & Percentage (\%) \\
\hline $26-35$ & Early Adult & 13 & 8 \\
$36-45$ & Late Adult & 41 & 26 \\
$46-55$ & Early Elderly & 55 & 35 \\
$56-65$ & Late Elderly & 49 & 31 \\
\hline Total & & 158 & 100 \\
\hline
\end{tabular}

Most respondents belonged to the category of early elderly; thirty-five percent (55 persons) ranged between 46 and 55 years old, followed by late elderly, thirty-one percent (49 persons), late adult, twenty-six percent (41 persons), and early adult, eight percent (13 persons). The composition of population according to the age structure of the inhabitants was an important indicator to see how much the people's reliability burden was. In relation to the age structure and production capacity, economically according to Human Development Index (IPM) 2018, the respondents belonged to the productive-age group. People in the productive-age are expected to become the backbones of driving the conomy in one area, so that their heavy reliability will not affect the pace of the economy in that area (BPS, 2019).

Educational Level. Educational level will influence knowledge, capability and expertise (Cindoswari, 2012; Nugraha, 2012; Utami, 2013). The respondents' educational level in this research did not vary a lot because the respondents were only taken from the farmers (Table 2).

Based on the results of Table 2 (next page), most farmers studied for more than 7 years with the category 'average' $27 \%$ (42 persons), 'high' $29 \%$ (45 persons), and 'very high' $3 \%$ (5 persons). If it is counted according to the average of length of study (ALS), the farmers' ALS is 8.59 years. According 
to this educational level, farmers belong to the category of people with RLS above the average in Indonesia in the year 2018, that is 8.17 years.

Table 2. Number and percentage of farmers according to the educational level, 2018

\begin{tabular}{lccc}
\hline Length of Study & Category & $\begin{array}{c}\text { Number of Respondents } \\
\text { (person) }\end{array}$ & Percentage (\%) \\
\hline$<7$ years & Low & 65 & 41 \\
$7-9$ years & Average & 42 & 27 \\
$10-12$ years & High & 45 & 29 \\
$>12$ years & Very High & 5 & 3 \\
\hline Total & & 158 & 100 \\
\hline
\end{tabular}

Farming Experience. The percentage of farmers according to farming experience can be seen in Table 3. Farming experience is how long farmers are directly involved in the management process of farming. Based on table 3, most farmers had very little experience in farming; fifty-two percent (83 persons) have 1 to 15 years' experience. Based on the farming duration, it can be seen that some farmers were still newcomers or they had not had enough experience in farming.

Table 3 Farmers' farming experience, 2018

\begin{tabular}{lccc}
\hline $\begin{array}{c}\text { Farming Duration } \\
\text { (years) }\end{array}$ & Category & $\begin{array}{l}\text { Number of Respondents } \\
\text { (person) }\end{array}$ & Percentage (\%) \\
\hline $1-15$ & New & 83 & 52 \\
$16-29$ & Experienced & 36 & 23 \\
$30-45$ & Very Experienced & 39 & 25 \\
\hline Total & & 100 & 100 \\
\hline
\end{tabular}

Join the farmer groups. Joining the farmer groups in this research means how long (in years) someone becomes a member of a farmer group. Joining a farmer group can be distinguished by the following: less than 5 years, between 5 and 10 years, and more than 10 years. From the research results (Table 4 ), it can be seen that the duration for farmers to join farmer groups is as follows: 49 percent (79 persons) have joined more than 10 years, 31 percent (49 persons) 5-10 years, and 20 percent ( 31 persons) less than 5 years.

Table 4 Farmers join Farmer Groups, 2018

\begin{tabular}{lcc}
\hline Duration of Joining & $\begin{array}{c}\text { Number of Respondents } \\
\text { (person) }\end{array}$ & Percentage (\%) \\
\hline$<5$ years & 31 & 20 \\
$5-10$ years & 49 & 31 \\
$>10$ years & 79 & 49 \\
\hline Total & 158 & 100 \\
\hline
\end{tabular}

Main Job and Side Job. Of the 158 respondents, the representatives of farmer groups, there were $85 \%$ (135 persons) whose main job was farming, while the other 15\% (23 persons) were farming labor, traders, and civil servants. Of the 158 respondents, 135 persons had side jobs: $13 \%$ as farming labor (20 persons), $1 \%$ as industrial entrepreneurs ( 2 persons), $18 \%$ as traders ( 28 persons), $1 \%$ as crafsmen ( 2 persons), and $1 \%$ as civil servants ( 2 persons). 
Land Area and Farming Commodities. The agricultural land area that was managed by farmers varied a lot or had a lot of varieties. Table 5 shows that in fact $48 \%$ of the land area managed by farmers was the same as $0.7 \mathrm{ha}$, whereas farmers that owned a land of $0.25-0.7$ ha are only $26 \%$ of the total respondents; the other 26 percent owned a land less than 0.25 ha. From the results we can conclude that the land area managed by farmers is relatively small.

Table 5 Farming land area owned by farmers, 2018

\begin{tabular}{lcc}
\hline Land Area (Ha) & $\begin{array}{c}\text { Number of Respondents } \\
\text { (person) }\end{array}$ & Percentage (\%) \\
\hline$<0.25$ & 41 & 26 \\
$0.25-0.7$ & 41 & 26 \\
$>0.7$ & 76 & 48 \\
\hline Total & 158 & 100 \\
\hline
\end{tabular}

The commodities that were cultivated by farmers were rice, non-rice products, rubber, fruits such as bananas and vegetables. All farmers grew rice. Besides rice, 19 farmers grew non-rice plants, 20 farmers grow vegetables and fruits, 2 farmers grow rubber, and 1 farmer grows ornamental plants.

In carrying out an agricultural development, the key to success lies in the farmers as the main subjects of the agricultural development (Syakir, 2015). Farmers are the subjects as well as the objects of the agricultural development (Syakir, 2015). Based on the identification of characteristics, respondents belonged to the productive-age category. The category of inhabitants with farmer ALS was 8.59 years and most of them were farmers. This shows that farmers have a potential to absorb the progress of agricultural technology innovation.

\section{Communication and Alsintan Performance}

The use of Alsintan before the assistance program. The use of alsintan before the assistance program was carried out (Table 6) is alsintan that had been used by farmers before government assistance program was carried out; this included 2 -wheeled hand tractors and water pumps. Of the 258 respondents, 73 percent (116 persons) had used the 2-wheeled hand tractors, while the rest 27 percent (42 persons) still used hues and buffaloes. Of the 17 respondents, only 47 percent ( 8 persons) used water pumps; the rest 53 percent ( 9 persons) used irrigation or rain water.

Table 6 The use of alsintan by farmers, 2018

\begin{tabular}{lcc}
\hline Types of Alsintan & $\begin{array}{c}\text { Number of Respondents } \\
\text { (person) }\end{array}$ & Percentage (\%) \\
\hline 2-Wheeled Hand Tractor & 116 & 73 \\
Already used & 42 & 27 \\
Not yet used & & \\
& & 47 \\
Water Pump & 8 & 53 \\
Already used & 9 & \\
Not yet used & & \\
\hline
\end{tabular}

Socialization of Alsintan Infrastructure. Types of alsintan that were provided by the government in 2015-2017 were 2-wheeled hand tractors and water pumps (Table 7). The number of respondents who got 2-wheeled hand tractors was 100 percent (158 persons), while those who got water pumps were only 11 percent (17 persons).

The socialization of infrastructure is a series of extension activities provided for the farmers about a product, how to operate it and to demonstrate it. Of the 158 respondents, 77 percent (122 persons) took part in the socialization of the 2-wheeled hand tractors, whereas the other 18 percent (18 persons) did not join in the socialization program. Those who took part in the socialization and demonstration 
of water pumps were 73 percent (115 persons), and the other 13 percent (20 persons) did not take part in the socialization program. The time for socialization was before, upon and after alsinta was given in the meetings.

Of the 158 respondents, only 17 persons got water pump assistance. Of the 17 respondents, about 94 percent (16 persons) took part in the product socialization, how to operate it and to demonstrate it, while the other 6 percent (1 person) did not join in the socialization program because he was working in the field.

Table 7 Alsintan socialization to farmers, 2018

\begin{tabular}{|c|c|c|c|c|}
\hline \multirow[t]{2}{*}{ Types of Socialization } & \multicolumn{2}{|c|}{ 2-wheeled Hand Tractor } & \multicolumn{2}{|c|}{ Water Pump } \\
\hline & $\begin{array}{c}\text { Number of } \\
\text { Respondents } \\
\text { (person) }\end{array}$ & $\begin{array}{c}\text { Percentage } \\
(\%)\end{array}$ & $\begin{array}{c}\text { Number of } \\
\text { Respondents } \\
\text { (person) }\end{array}$ & $\begin{array}{c}\text { Percentage } \\
(\%)\end{array}$ \\
\hline \multicolumn{5}{|l|}{ Product Socialization } \\
\hline Yes & 122 & 77 & 16 & 94 \\
\hline No & 18 & 18 & 1 & 6 \\
\hline \multicolumn{5}{|l|}{$\begin{array}{l}\text { Socialization of } \\
\text { Operating and }\end{array}$} \\
\hline Demonstrating the & 115 & 73 & 16 & 94 \\
\hline Tools & 20 & 13 & 1 & 6 \\
\hline \multicolumn{5}{|l|}{ Yes } \\
\hline \multicolumn{5}{|l|}{ No } \\
\hline \multicolumn{5}{|l|}{ Time for } \\
\hline Before submission & 2 & 1 & 0 & 0 \\
\hline Upon submission & 119 & 75 & 16 & 94 \\
\hline $\begin{array}{l}\text { Before and after the } \\
\text { submission }\end{array}$ & 1 & 1 & 0 & 0 \\
\hline
\end{tabular}

Socialization is one of the important communication activities to drive the process of dispersal and application of technology in a rural social (Indraningsih, 2018). Innovation can give benefits to farmer community if the technology given can be applied well. For that reason, information on technology must be widespread through various methods of communication and communication media which will support the activities and in turn will help farmers to increase efficiency in managing their farming activities (Indraningsih, 2018). The number of respondents that attended the product socialization and how the 2-wheeled hand tractors worked presented before and after the program was only 77 percent while those attended the socialization and how the water pumps worked were 94 percent. This means that socialization have not reached all farmers, the receivers of the program. The information delivery that was still low can result in the low of innovation adoption (Syakir, 2015).

Condition of Alsintan Utility. The condition of alsintan utility in this research means the rate of intake of the equipment by saying 'accept' or 'reject', the rate of its availability by saying 'Yes' or 'No', and the rate of the equipment usage whether it has been used or not. The condition of the equipment utility includes the use of 2-wheeled hand tractors and water pumps (Table 8).

The rate of acceptance of 2-wheeled hand tractor of the respondents was the 158 respondents accepted the equipment and they had used the equipment. Based on the availability rate, there was only $82 \%$ (130 persons) whose equipment was still available and usable, while the other $18 \%$ (28 persons) said the equipment was no longer available because it was lost or damaged.

Based on the rate of acceptance of the water pump, as many as 17 respondents accepted it. Based on the availability rate, $100 \%$ (17 persons) said it was still available. Based on the usage, only $76 \%$ (13 persons) said the equipment was still usable, whereas the other $24 \%$ said it could no longer be used. Some reasons the farmers gave why they did not the water pump because the river was dry, it needed 
to be modified first, there was no space to keep the equipment in their farm land so that the risk of losing would be high. To keep the equipment, farmers needed to have a safe place to keep it because the location of the land was far from home.

Table 8 Condition of alsintan utilization by farmers, 2018

\begin{tabular}{lrr}
\hline Types of Alsintan & $\begin{array}{r}\text { Number of Respondents } \\
\text { (person) }\end{array}$ & $\begin{array}{r}\text { Percentage } \\
(\boldsymbol{\%})\end{array}$ \\
\hline 2-Wheeled Hand Tractor & & 100 \\
Acceptance rate on the procurement of equipment & 0 & 0 \\
Accept & 130 & 82 \\
Reject & 28 & 18 \\
Procurement rate of equipment & & 100 \\
Yes & 158 & 0 \\
No & 0 & \\
Equipment usage rate & & 100 \\
Already used & & 0 \\
Not yet used & 17 & 100 \\
Water Pump & 0 & 0 \\
Acceptance rate on the procurement of equipment & & \\
Accept & 17 & 76 \\
Reject & 0 & 24 \\
Procurement rate of equipment & & \\
Yes & 13 & \\
No & 4 & \\
Equipment usage rate & & \\
Already used & & \\
Not yet used & &
\end{tabular}

\section{Innovation Attributes}

Relative Advantage. The relative advantage in this research is the rate of advantage or benefit of the equipment from the aspect of economy as well as status. Some questions that were posed, among others, are: whether there was an advantage/benefit in using the equipment in terms of reduced production cost, reduced time of operating, reduced inefficiency or making work easier, increased production after using it, and improved income (Table 9).

Table 9 Advantage/benefit of using alsintan according to farmers, 2018

\begin{tabular}{lcc}
\hline Types of Alsintan & $\begin{array}{c}\text { Number of } \\
\text { Respondents } \\
\text { (person) }\end{array}$ & $\begin{array}{c}\text { Percentage } \\
(\mathbf{\%})\end{array}$ \\
\hline 2-Wheeled Hand Tractor & & \\
Cheaper production cost & 155 & 98 \\
Yes & 3 & 2 \\
No & 156 & 98 \\
Faster operation & 2 & 2 \\
Yes & 158 & 100 \\
No & 0 & 0 \\
Less inconvenience/easier operation & & \\
Yes & 154 & 97 \\
No & 4 & 3 \\
Increased Production & & \\
Yes & 150 & 95 \\
No & 8 & 5 \\
Increased Income & & \\
Yes & & \\
No & & \\
\hline
\end{tabular}




\begin{tabular}{lcc}
\hline Types of Alsintan & $\begin{array}{c}\text { Number of } \\
\text { Respondents } \\
\text { (person) }\end{array}$ & $\begin{array}{c}\text { Percentage } \\
(\%)\end{array}$ \\
\hline Water Pump & & \\
Cheaper production cost & & 76 \\
Yes & 13 & 24 \\
No & 4 & 100 \\
Faster operation & 17 & 0 \\
Yes & 0 & 76 \\
No & & 24 \\
Less inconvenience/easier operation & 13 & 58 \\
Yes & 4 & 42 \\
No & & \\
Increased Production & 10 & 47 \\
Yes & 7 & 53 \\
No & & \\
Increased Income & 8 & \\
Yes & 9 & \\
No & & \\
\hline
\end{tabular}

Of the 158 respondents who had used 2-wheeled hand tractor, 95\% (150 persons) said that by using hand tractor their production cost was reduced, $91 \%$ (144 persons) said it could speed-up their work, 94\% (149 persons) said it could increase production, and 60\% (95 persons) said it could increase their income.

From the open question, 4 persons said that there was in increase in production of 5-20 percent, 2 persons 30-40 percent, and 5 persons 50-70 percent. Two respondents said there was a 5-percent increase in income, 5 persons a 30-percent increase, and 2 persons said there was no certain increase.

Of the 17 respondents who got water pump aid, about 76 percent (13 persons) said that using a water pump could reduce production cost and made it easier to do the job, 29 percent ( 5 persons) said that it could increase production and 18 percent ( 3 persons) said it could increase their income. This means that a relative advantage is more dominant because it can cut production cost and accelerate the job.

It can be said that a relative advantage of using hand tractor and water pump is more dominant because it can reduce production cost, accelerate the job, and increase production. This is in line with the findings by Asnamawati (2015), Rushendi (2017), Harianta (2010), Noppers et al. (2016) and Jones (2006) which stated that the first thing the target people see when adopting an innovation is the advantage that the adopters get. It is different from the finding by Heffernan et al. (2008) who said that an advantage is not the main factor in adopting a vaccine innovation.

Suitability. Suitability in this research means suitability of the existence of the equipment with the current cultural values and suitability with the previously-introduced ideas. The results from Table 10 (next page) showed that of the 158 respondents who had used 2-wheeled hand tractors, most of them i.e., $95 \%$ (150 persons) said that the use of hand tractor did not contradict to the current cultural values and its presence was in accordance with the previously-introduced ideas. Of the 17 respondents who got pump water aid, most of the i.e., 94\% (13 persons) said that water pumps did not contradict with the current cultural values and their existence were in accordance with the previously-introduced ideas.

From the results of the condition of alsintan usage before the assistance program was conducted, $73 \%$ respondents had used hand tractor, and $47 \%$ of them respondents had used water pumps. The suitability of innovation and habit, experience and the target people's cultural values becomes a benchmark to adopt an innovation (Adnan et al., 2019; Asnamawati, 2015), and it plays an important role to increase the target people's awareness (Aubert et al., 2012). 
Table 10 Innovation suitability according to farmers, 2018

\begin{tabular}{lcc}
\hline Types of Alsintan & $\begin{array}{c}\text { Number of } \\
\text { Respondents } \\
\text { (person) }\end{array}$ & $\begin{array}{c}\text { Percentage } \\
(\%)\end{array}$ \\
\hline 2-Wheeled Hand Tractor & & \\
Equipment suitable with existing cultural values & 155 & 98 \\
Yes & 3 & 2 \\
No & 156 & 98 \\
Equipment suitable with needs & 2 & 2 \\
Yes & & \\
No & & 94 \\
Water Pump & 16 & 6 \\
Equipment suitable with existing cultural values & 1 & 94 \\
Yes & & 6 \\
No & 16 & \\
Equipment suitable with needs & 1 & \\
Yes & & \\
No & & \\
\end{tabular}

Complexity. Complexity in this research means the rate of difficulty in using the equipment. The categorization of difficulty rate uses the likert scale, namely more difficult, the same, and easier (Table $11)$.

After the complexity was categorized, it appeared that 26 percent (41 persons) respondents said that 2wheeled hand tractor was easier to use and 1 percent (1 person) said that it was more difficult compared with using hues or buffaloes. One hundred nine respondents $(69 \%)$ said that it was easier compared with using the previous hand tractor, five persons ( 3 percent) said that it was the same, and 2 persons (1 percent) said it was difficult because they usually used rented hand tractor.

Of the 17 respondents who had got water pump aid, there was 47 percent who said that it was easier to use and 6 percent said that it was very difficult to use compared with manual irrigation, and 47 percent said that it was the same as the previous water pump. From the results of the research, it can be concluded that 2-wheeled hand tractors and water pumps given according to most farmers are easier to operate. The easiness of a technology becomes a priority for target people in adopting an innovation (Asnamawati, 2015; Efendy \& Hutapea, 2010; Trischler et al., 2020; Warnaen et al., 2013). Rushendi (2017) found that an agricultural innovation of lemongrass bioindustry is difficult to practice; therefore, it needs a demonstration, training and sampling.

Table 11 Innovation complexity according to farmers, 2018

\begin{tabular}{ccc}
\hline Types of Alsintan & $\begin{array}{c}\text { Number of } \\
\text { Respondents } \\
\text { (person) }\end{array}$ & $\begin{array}{c}\text { Percentage } \\
(\%)\end{array}$ \\
\hline
\end{tabular}

\section{2-Wheeled Hand Tractor}

Easiness to use the equipment compared with

buffaloes or hues

More difficult

The same

$1 \quad 1$

Easier

4126

Easiness to use the equipment compared with previous tractor

More difficult

1 


\begin{tabular}{lcc}
\hline Types of Alsintan & $\begin{array}{c}\text { Number of } \\
\text { Respondents } \\
\text { (person) }\end{array}$ & $\begin{array}{c}\text { Percentage } \\
(\mathbf{\%})\end{array}$ \\
\hline The same & 5 & 3 \\
Easier & 109 & 69 \\
Water Pump & & \\
Easiness to use the equipment compared with manual & & \\
pump & & 6 \\
More difficult & 1 & 0 \\
The same & 0 & 47 \\
Easier & 8 & 0 \\
Easiness to use the equipment compared with & & 0 \\
previous water pump & & \\
More difficult & 0 & \\
The same & 8 & 0 \\
Easier & 0 & \\
& & \\
\hline
\end{tabular}

Trialability. Trial in this research means whether demonstration and test of the tool before it is used are carried out or not. The categorization of trial level uses an interval scale, namely yes or no (Table 12).

Of the 158 respondents, 78 percent (124 persons) that had used 2-wheeled hand tractors said that they were present during the demonstration and test of the tool, while 22 percent ( 34 persons) said that they were not. Of the 17 respondents that had water pumps, about 80 percent (14 persons) were present in the demonstration, and 20 percent ( 3 persons) were not.

Table 12 Innovation trial according to farmers, 2018

\begin{tabular}{lcc}
\hline Types of Alsintan & $\begin{array}{c}\text { Number of } \\
\text { Respondents } \\
\text { (person) }\end{array}$ & $\begin{array}{c}\text { Percentage } \\
(\boldsymbol{\%})\end{array}$ \\
\hline 2-Wheeled Hand Tractor & & \\
There was a tool demonstration beforehand & 124 & 78 \\
Yes & 34 & 22 \\
No & & 80 \\
Water Pump & 14 & 20 \\
There was a tool demonstration beforehand & 3 & \\
Yes & & \\
No & & \\
\hline
\end{tabular}

From the results, it can be concluded that most respondents managed to try the tool during the demonstration session of the agricultural machinery. Prior to the assistance program, seventy-three percent respondents had used the 2-wheeled hand tractors, and forty-seven percent respondents had used water pumps. According to Aubert et al. (2012) and Efendy \& Hutapea (2010) trial is a strong predictor towards innovation adoption.

Visibility. Visibility in this research means whether the results of using the equipment can be seen instantly or not. The categorization of visibility rate uses an interval scale: Yes, No, or NA. the results in Table 13 showed that of the 150 respondents that had used two-wheeled hand tractors, 96 percent (152 persons) said that the results of using the equipment could be seen directly, while four percent (6 persons) said they could not see the result. On the other hand, 100 percent respondents (17 persons) who had got water pumps said that they could see the result instantly. From the results it can be 
concluded that according to most farmers the results of the given two-wheeled hand tractors and water pumps could be seen instantly. Hand tractors and water pumps are hardware innovations whose application in the field can be seen directly from the speed to finish the work of processing the land and watering plants. The finding by Rushendi (2017) and Harianta (2010) shows that farmers adopt innovation because the results can be seen from the advantage or results of using the innovation.

Table 13 Innovation visibility according to farmers, 2018

\begin{tabular}{lrr}
\hline Types of Alsintan & $\begin{array}{c}\text { Number of } \\
\text { Respondents } \\
\text { (person) }\end{array}$ & $\begin{array}{c}\text { Percentage } \\
\text { (\%) }\end{array}$ \\
\hline $\begin{array}{l}\text { 2-Wheeled Hand Tractor } \\
\text { Hasil dari penggunaan alat dapat terlihat langsung } \\
\text { hasilnya }\end{array}$ & & \\
Ya & 152 & 96 \\
Tidak & 6 & 4 \\
Water Pump & & \\
Hasil dari penggunaan alat dapat terlihat langsung & & \\
hasilnya & 17 & 100 \\
Ya & 0 & 0 \\
$\quad$ Tidak & & \\
\hline
\end{tabular}

From the results of observing the condition of alsintan usage before the assistance program, about 73 percent respondents had used hand tractors while the rest still used hues or buffaloes, and only 47 percent respondents had used water pumps, while the rest used irrigation or rain water. When the alsintan assistance program was given, the socialization programs were carried out prior to, after, and before and after the program through some meetings. Socialization is important to support the process of distribution and application of innovation (Indraningsih, 2018). Socialization that has been given has not reached all farmers, the receivers of the program, while information delivery can increase innovation adoption. Innovation can give benefits to farmers if technology given can be applied well.

If the characteristics of innovation in adopting alsintan innovation by farmers are summarized in one graph (Figure 1), it can be seen that farmers adopt hand tractor innovation because it is less costly, faster, in accordance with culture and needs, triable, and visible. This shows that during the identification period, the condition of alsintan usage, respondents' acceptance to innovation is high.

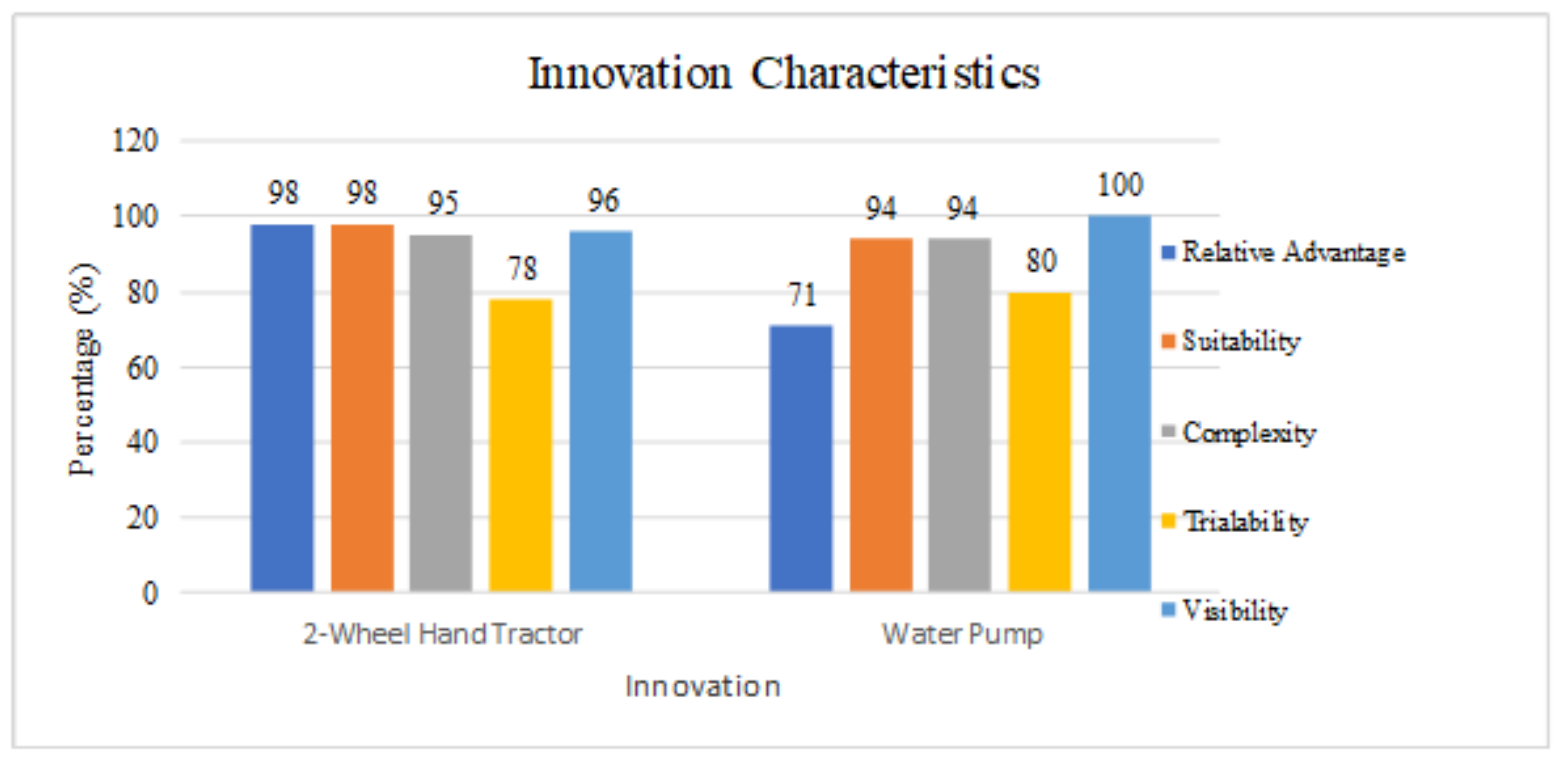

Figure 1. Innovation Characteristics in adopting the innovation of Hand Tractor and Water Pump, 2018 
Two-wheeled hand tractor and water pump innovations have been mostly utilized by farmers. Farmers utilized innovations because there are some relative advantages, suitability with culture and needs, easy to use, triable and visible. This is in line with statement by Gandasari (2020), and findings by Serah (2013), Efendy \& Hutapea (2010), Harianta (2010) and Asnamawati (2015) which stated that innovation application was influenced by advantages; comfortability, satisfaction, suitability with environment and values, easiness to apply and to try, and easiness to see the results. There was a kind of rationality behind an individual's and group's decision when applying innovation (Laguna et al., 2019).

The theoretical implication of this research is it can enrich applied research in the field of agricultural development communication, especially in adopting agricultural innovation by measuring the innovation characteristics according to Rogers (2003).

The practical implications of this research are as follows: (1) since the key characteristic to success lies in farmers as the main actors of agricultural development, farmers' characteristics (including productive age, high literacy, and profession as farmers) must have a potential to absorb innovation progress in agricultural technology; (2) individual's and group's decision in applying innovation is influenced by innovation characteristics; and (3) innovation communication prior to, upon and after the assistance program is needed for the sustainability of the innovation adoption.

\section{CONCLUSION}

Innovation characteristics consist of relative advantage, compatibility, complexity, trialability and visibility. Based on the results of analysis on innovation adoption of 2-wheeled hand tractors and water pumps, all respondents have accepted the innovation because both innovation tools have the following characteristics: 1) Relative advantage, among others, they reduce production cost, they make work easier, and they increase production; 2) Compatibility, in accordance with culture and needs; 3 ) Complexity, they are easier to use; 4) Trialability, a trial is carried out before use and completed with tutorial; and 5) Visibility, the results can be seen.

Farmers' perception on the given innovation message becomes the determining factor in the adoption process of innovation. Mentoring and coaching by the researchers and extension workers are needed to support the process of technological acceleration. Innovation communication in the alsintan program needs to be adapted to the characteristics of farmers, level of needs, availability of materials and supporting tools in the neighboring area. Some driving factors of innovation adoption are environment, organization and individual that will give impacts and determine different priorities in various locations because the adoption is dynamic and changeable in line with time (Tutusaus \& Schwartz, 2018). Therefore, it is necessary to carry out further research to analyze the environment, organization and individual as driving factors of innovation adoption to find out why and how technology is distributed by means of understanding organization innovation as a set of decisions related to individual characteristics, internal structure characteristics of organization and external factors.

\section{REFERENCES}

Adekambi, S. A., Okello, J. J., Abidin, P. E., \& Carey, E. (2020). Effect of exposure to biofortified crops on smallholder farm household adoption decisions: The case of orange-fleshed sweetpotato in Ghana and Nigeria. Scientific African, 8, e00362. https://doi.org/https://doi.org/10.1016/j.sciaf.2020.e00362

Adnan, N., Nordin, S. M., Bahruddin, M. A., \& Tareq, A. H. (2019). A state-of-the-art review on facilitating sustainable agriculture through green fertilizer technology adoption: Assessing farmers behavior. Trends in Food Science and Technology, 86(February), 439-452. https://doi.org/https://doi.org/10.1016/j.tifs.2019.02.040

Alemayehu, A. G., Gebreeyesus, A., Palladino, G., \& Setti, M. (2020). Behavioral precursors in the innovation-decision process: The case of bioenergy in Ethiopia. Energy Strategy Reviews, 30(April), 100499. https://doi.org/https://doi.org/10.1016/j.esr.2020.100499

Asnamawati, L. (2015). Strategi Percepatan Adopsi dan Difusi Inovasi Dalam Pemanfaatan Mesin Tanam Padi Idojarwo Tansplanter Di Kabupaten Bengkulu Utara Provinsi Bengkulu. Universitas 
Terbuka-UPBJJ Bengkulua.

Aubert, B. A., Schroeder, A., \& Grimaudo, J. (2012). IT as enabler of sustainable farming: An empirical analysis of farmers' adoption decision of precision agriculture technology. Decision Support Systems, 54(1), 510-520. https://doi.org/https://doi.org/10.1016/j.dss.2012.07.002

Bavorová, M., Unay-Gailhard, İ., Ponkina, E. V., \& Pilařová, T. (2020). How sources of agriculture information shape the adoption of reduced tillage practices? Journal of Rural Studies, 79(August), 88-101. https://doi.org/https://doi.org/10.1016/j.jrurstud.2020.08.034

Cindoswari, A. R. (2012). Jaringan Komunikasi Dalam Penerapan Teknologi Produksi Ubi Kayu (Kasus Petani Ubi Kayu Di Desa Suko Binangun, Kecamatan Way Seputih, Kabupaten Lampung Tengah, Provinsi Lampung). Institut Pertanian Bogor.

Deng, J., Sun, P., Zhao, F., Han, X., Yang, G., \& Feng, Y. (2016). Analysis of the ecological conservation behavior of farmers in payment for ecosystem service programs in ecoenvironmentally fragile areas using social psychology models. Science of the Total Environment, 550, 382-390. https://doi.org/10.1016/j.scitotenv.2016.01.152

Efendy, J., \& Hutapea, Y. (2010). Analisis Adopsi Inovasi Teknologi Pertanian Berbasis Padi di Sumatera Selatan dalam Perspektif Komunikasi. Jurnal Pengkajian Dan Pengembangan Teknologi Pertanian, 13(2), 119-130.

Frank, B. R. (1995). Constraints limiting innovation adoption in the north Queensland beef industry. I: A socio-economic means of maintaining a balanced lifestyle. Agricultural Systems, 47(3), 291321.

Frank, B. R. (1997). Adoption of innovations in the North Queensland beef industry. III: Implications for extension management. Agricultural Systems, 55(3), 347-358. https://doi.org/https://doi.org/10.1016/0308-521X(95)90745-F

Gandasari, D. (2020). Komunikasi Inovasi: Pendampingan Mahasiswa dan Bina Desa pada Masa Covid-19. In A. Rikki (Ed.), Belajar dari COVID-19: Perspektif Teknologi \& Pertanian. Yayasan Kita Menulis.

Harianta, Y. W. (2010). Faktor-Faktor Yang Mempengaruhi Kecepatan Adopsi Inovasi Pertanian Di Kalangan Petani Di Kecamatan Gatak Kabupaten Sukoharjo. Journal of Chemical Information and Modeling, 53(9), 1689-1699.

Heffernan, C., Thomson, K., \& Nielsen, L. (2008). Livestock vaccine adoption among poor farmers in Bolivia: Remembering innovation diffusion theory. Vaccine, 26(19), 2433-2442. https://doi.org/https://doi.org/10.1016/j.vaccine.2008.02.045

Indraningsih, K. S. (2018). Agricultural Innovation Dissemination Strategy in Supporting Agricultural Development. Forum Penelitian Agro Ekonomi, 35(2), 107-123. https://doi.org/http://dx.doi.org/10.21082/fae.v35n2.2017.107-123

Jones, G. E. (2006). Modelling farmer decision-making: Concepts, progress and challenges. Animal Science, 82(6), 783-790. https://doi.org/https://doi.org/10.1017/ASC2006112

Kurnia, G. (2014). Difusi Inovasi Jaring Pengusir Burung Pada Kelompok Tani Sumber Makmur Di Desa Kalibelo, Kecamatan Gampengrejo, Kabupaten Kediri. Commonline, 3(1).

Laguna, M. F., Iglesias, J. R., \& Goncalves, S. (2019). Irrational behavior on the adoption of innovations. Physica A: Statistical Mechanics and Its Applications, 535(1 December), 122388. https://doi.org/https://doi.org/10.1016/j.physa.2019.122388

Luo, L., Qin, L., Wang, Y., \& Wang, Q. (2016). Environmentally-friendly agricultural practices and their acceptance by smallholder farmers in China-A case study in Xinxiang County, Henan Province. Science of the Total Environment, 571, 737-743.

https://doi.org/10.1016/j.scitotenv.2016.07.045

Noppers, E. H., Keizer, K., Milovanovic, M., \& Steg, L. (2016). The importance of instrumental, symbolic, and environmental attributes for the adoption of smart energy systems. Energy Policy, 98(November 2016), 12-18. https://doi.org/https://doi.org/10.1016/j.enpol.2016.08.007 
Nugraha, Y. A. (2012). Hubungan Orang Tua, Media Massa dan Teman dengan Sikap Pemuda Terhadap Pekerjaan di Bidang Pertanian. Kasus Pemuda di Desa Cipendawa dan Desa Sukatani, Kecamatan Pacet Kabupaten Cianjur. Institut Pertanian Bogor.

Page, G., \& Bellotti, B. (2015). Farmers value on-farm ecosystem services as important, but what are the impediments to participation in PES schemes? Science of the Total Environment, 515-516, 12-19. https://doi.org/10.1016/j.scitotenv.2015.02.029

Pagliacci, F., Defrancesco, E., Mozzato, D., Bortolini, L., Pezzuolo, A., Pirotti, F., Pisani, E., \& Gatto, P. (2020). Drivers of farmers' adoption and continuation of climate-smart agricultural practices. A study from northeastern Italy. Science of the Total Environment, 710, 136345. https://doi.org/https://doi.org/10.1016/j.scitotenv.2019.136345

Rogers, E. M. (1962). Diffusion of innovations. The Free Press.

Rushendi. (2017). Komunikasi Inovasi Pertanian Bioindustri (Kasus Pengembangan Pertanian Bioindustri Integrasi Serai Wangi - Ternak) RUSHENDI. Institut Pertanian Bogor.

Sasongko, W. A. (2016). Pengaruh Perilaku Komunikasi Terhadap Sikap Dan Adopsi Teknologi Budidaya Bawang Merah Di Lahan Pasir Pantai Kecamatan Sanden Kabupaten Bantul. Agro Ekonomi, 25(1). https://doi.org/https://doi.org/10.22146/agroekonomi.17380

Serah, T. (2013). Pengaruh Karakteristik Inovasi Sistem Sosial Dan Saluran Komunikasi Terhadap Adopsi Inovasi Teknologi Pertanian. Journal Universitas Atma Jaya Yogyakarta.

Sulaiman, A. A., Herodian, S., Hendriadi, A., Jamal, E., Prabowo, A., Prabowo, A., Mulyantara, L. T., Budiharli, U., Syahyuti, \& Hoerudin. (2018). Revolusi Mekanisasi Pertanian. IAARD Press.

Syakir, M. (2015). Pemantapan Inovasi dan Diseminasi Teknologi dalam Memberdayakan Petani. Prosiding Seminar Nasional Perlindungan Dan Pemberdayaan Pertanian Dalam Rangka Pencapaian Kemandirian Pangan Nasional Dan Peningkatan Kesejahteraan Petani, 3-14.

Trischler, J., Johnson, M., \& Kristensson, P. (2020). A service ecosystem perspective on the diffusion of sustainability-oriented user innovations. Journal of Business Research, 116(January), 552560. https://doi.org/https://doi.org/10.1016/j.jbusres.2020.01.011

Tutusaus, M., \& Schwartz, K. (2018). The ambiguity of innovation drivers: The adoption of information and communication technologies by public water utilities. Journal of Cleaner Production, 171(Supplement), 579-585.

Utami, D. (2013). Jaringan Komunikasi Informasi Harga dan Pemasaran Sayur. Institut Pertanian Bogor.

Wadsworth, J. (1995). Adoption of innovations by Costa Rican livestock producers under different levels of extension intensity: Predicted versus observed behaviour. Agricultural Systems, 49(1), 69-100. https://doi.org/https://doi.org/10.1016/0308-521X(94)00017-L

Warnaen, A., Cangara, H., \& Bulkis, S. (2013). Faktor-faktor yang Menghambat Komunikasi pada Kumunitas Petani dan Nelayan dalam Meningkatkan Kesejahteraan Masyarakat di Kabupaten Takalar. Kareba, 02(03), 241-250.

Warnaen, A., Nurlaili, \& Romadi, U. (2016). Proses Adopsi Inovasi pada Petani di Kecamatan Polombangkeng Utara Kabupaten Takalar. Agrica Ekstensia, 10(2), 67-73. 